\title{
Filosofia da Educação e Infância: em busca de potências descolonizadoras I.
}

\author{
Débora Silva Pinto*, Silvio Gallo
}

\section{Resumo}

O presente projeto constrói uma análise crítica do processo de conformação e colonização da infância pela pedagogia e pela filosofia modernas. Para tal, tem-se como eixo o pensamento do filósofo contemporâneo francês René Schérer. Parte-se da ideia de que a infância é uma invenção dos adultos e o processo educativo o mecanismo para, de um lado, infantilizar as crianças e, de outro, conduzi-las à condição adulta. Portanto, na contramão desta crítica, pretende-se buscar elementos conceituais que construam uma perspectiva não colonizada da infância, tomando-a como "infância maior" (Schérer), na perspectiva de um devir-criança (Deleuze \& Guattari).

\section{Palavras-chave: \\ Infância; Educação; Perspectiva descolonizadora.}

\section{Introdução}

Desconsiderar a infância e pensar no que ela deve vir a ser, nada mais é do que conduzir para um lugar já dado. Ou seja, ignora a sua importância bem como aufere a própria liberdade. Sendo assim, esse projeto fala sobre a descolonização da infância que é justamente essa ruptura de paradigmas que a minimizam e a conduzem à condição adulta. Para além disso, este projeto também se trata de pensar sobre a emancipação da criança, onde o processo educativo dá-se junto com ela e não normatizando e ditando suas ações.

\section{Resultados e Discussão}

Segundo Sandra Mara Corazza, as crianças estão sempre aquém da essência e da subjetividade que lhes são atribuídas. Tendo isso, é de suma importância pensar no direito da infância que vai muito além de leis que a defendam, mas sim sobre pensar em aparatos e dispositivos que devem ser criados para ampará-las. Através deste pensamento a autora problematiza o porquê a infância tem que ser uma etapa que é a primeira a ser reprimida e superada para que possamos ir em direção a outros estágios (entre a puberdade e a velhice)?

Ao longo do livro Corazza deixa claro que a sociedade estaria cometendo a retirada da infância e a possibilidade de ser infantil. Sendo assim, a autora apresenta a necessidade de buscar uma infância sem fim e, por isso, o nome do livro é "História da infância sem-fim".

Criança e infância são categorias históricas e carregam uma ampla multiplicidade - raça, gênero, sexualidade e cidadania - Tendo isso como base, o livro: "Infância e pós-estruturalismo" de Anete Abramowicz, fala a respeito da infância na contemporaneidade a partir de concepções teóricas tais como Deleuze e Foucaul; e trata sobre as diferenças, as múltiplas possibilidades e sobre a singularidade. Para a autora, a infância é a própria liberdade de não ser adulto.

"A escola não tem infância" (Walter Kohan). Abramowicz ao fazer tal citação logo na introdução do seu livro cria um disparate para a ideia da infância roubada. Ou seja, crianças ao serem escolarizadas, precocemente alfabetizadas e colonizadas pela escola, tem como consequência desse processo o fracasso escolar, o racismo precoce, e a interdição do corpo/brincadeira/alegria. Todos esses sinais se fazem presentes não somente na atual conjuntura, mas há algum tempo na sociedade.

No livro "Infância, experiência e tempo", Cesar Leite problematiza a respeito da infância, se ela é capaz de ser definida, descrita ou antecipada. No decorrer da leitura, observa-se que ele vai na contramão deste determinismo causalista.

Por fim, deixo aqui duas citações que considero primordiais para a compreensão dessa temática, são elas: "Talvez o que as crianças tenham de mais potente seja a infância. " (ABRAMOWICZ; TEBET, 2017, p.25). "Na criança vejo a possibilidade subversiva de romper com a lógica predefinida." (LEITE,2011, p. 61).

\section{Conclusões}

A partir das bases teóricas obtidas para a construção desse projeto, concluo que a infância não deve ser algo fechado e pronto, previamente definido; simplesmente porque não se minimiza uma fase que é completa por si só. Sendo assim, este projeto compreende que o infantil é um ser-si e, portanto, a fase da infância deve ser respeitada.

\section{Agradecimentos}

Em primeiro lugar agradeço a minha mãe que sempre contribuiu nos meus estudos, agradeço também ao meu professor orientador Silvio Gallo e a minha companheira de projeto Júlia Smidt.

ABRAMOWICZ, Anete; TEBET, Gabriela (org.). Infância e pósestruturalismo. São Paulo: Porto de Ideias, 2017.

CORAZZA, Sandra Mara. História da Infância Sem Fim. Ijuí: Ed. UNIJUÍ, 2000 .

LEITE, César D. P. Infância, experiência e tempo. São Paulo: Cultura Acadêmica, 2011.

SCHÉRER, René. Infantis. Belo Horizonte: Autêntica, 2009. 